GEOLOGICAL SURVEY CIRCULAR 549

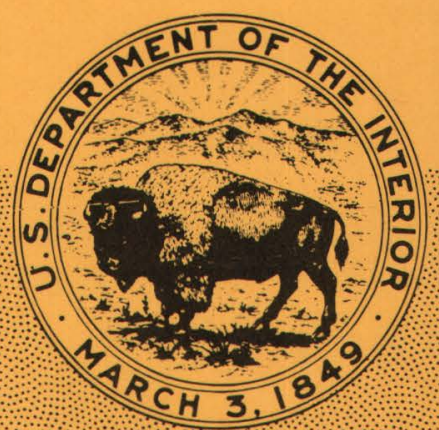

Economic Significance of Revised Age Relations of Rocks in the Cornucopia Mining District

Elko County, Nevada 



\section{Economic Significance of Revised Age Relations of Rocks in the Cornucopia Mining District Elko County, Nevada}

By R. R. Coats

GEOLOGICAL SURVEY CIRCULAR 549

Revision of geological interpretation and inferred

possible unmined extensions of silver ore bodies

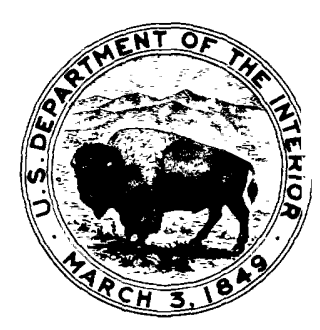


United States Department of the Interior STEWART L. UDALL, Secretary

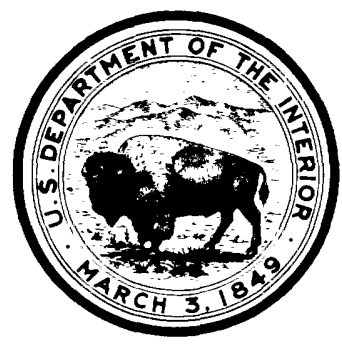

\section{Geological Survey}

William T. Pecora, Director

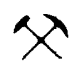




\section{CONTENTS}

\begin{tabular}{|c|c|c|}
\hline & Page & \\
\hline Abstract & 1 & Geology --- \\
\hline ntroduction & 1 & rences cited $\varepsilon_{-}$ \\
\hline
\end{tabular}

\section{ILLUSTRATIONS}

Figure 1. Index map of Elko County, Nev., showing location of the Cornucopia mining district

2. Geologic sketch map of the Cornucopia mining district 



\title{
ECONOMIC SIGNIFICANCE OF REVISED AGE RELATIONS OF ROCKS IN THE CORNUCOPIA MINING DISTRICT, ELKO COUNTY, NEVADA
}

\author{
By R. R. COATS
}

\begin{abstract}
Abstraci
Recent geologic work in the Cornucopia mining district, a small silver-gold mining district in northwestern Elko County, Nev., has resulted in significant revision of the geological interpretation. Rocks formerly thought to be premineralization in age, but unmineralized, are now known to be postmineral extrusives, resting unconformably on the altered andesite in which the ore bodies are found. Extensions of the known productive veins may be expected at shallow depth beneath the younger volcanic rocks, and are separated from the mined part of the veins by postmineral high-angle faults that have brought the younger volcanic rocks into fault contact with the mineralized andesite. Some veins are apparently terminated against premineral faults.
\end{abstract}

\section{INTRODUCTION}

The Cornucopia district is a silver-gold mining district in northwestern Elko County, Nev., (fig. 1). According to Granger, Bell, Simmons, and Lee (1957, p. 41) it has had a production of about $\$ 11 / 4$ million in gold and silver, ninetenths before 1883 . The silver-gold ratio by

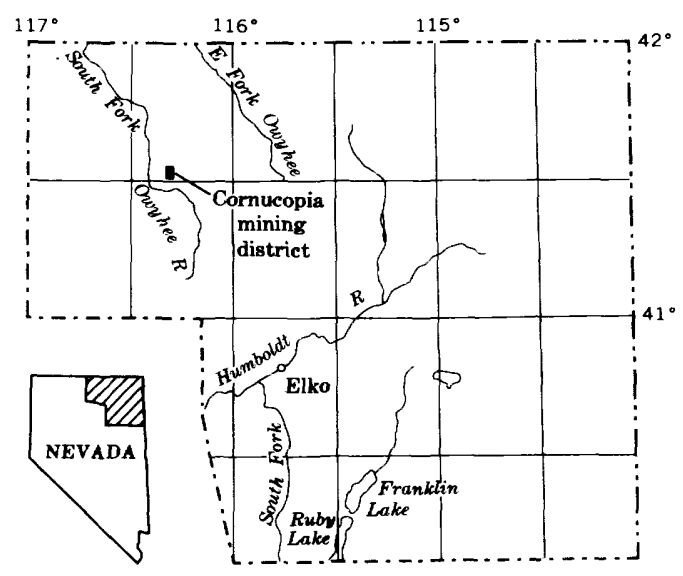

Figure 1.-Index map of Elko County, Nev., showing location of the Cornucopia mining district. weight for the latest productior was about 68:1; earlier records are not adequate to permit an estimate of the ratio.

\section{GEOLOGY}

The only available geological information is a brief report by Emmons (1910, p. 63-65), who visited the district in 1908 after mining had ceased and when most of the workings were inaccessible. Emmons recognized that the ore deposits are in altered andesite $\mathrm{s}$.nd that the hills "in the main, are capped with rhyolite and obsidian." He described the rhyolite as having a "glassy, microlitic groundmass and phenocrysts of quartz, oligoclase, pyroxere, magnetite and a little hornblende." Some phases of the rhyolite were said to be vesicular and some pumiceous. Emmons noted that tl $\circ$ accessible ore deposits are restricted to the andesite, but thought the andesite intruded the rhyolite.

The mines are no more accessible now than they were in 1908. In the course of a brief examination of the surface in 1966, I made the sketch map presented herewith (fig. 2). Fortunately, recent surficial prospecting disclosed critically important information on the rock relations.

The oldest exposed rock is the andesite in which the ore deposits occur. The fresher rocks examined in thin sections are pyroxene andesites. Most of the clinopyroxene is fresh augite; some patches of chlorite and nontronite appear to be pseudomorphs after orthopyroxene. More highly altered rocks are bleached and partly replaced by calcite, pyrite, and sericite. Some of these bleached rocks have nests of secondary quartz that simulate quartz phenocrysts in hand specimen.

The andesite and the mineral derosits that it contains are overlain unconformably by a series 


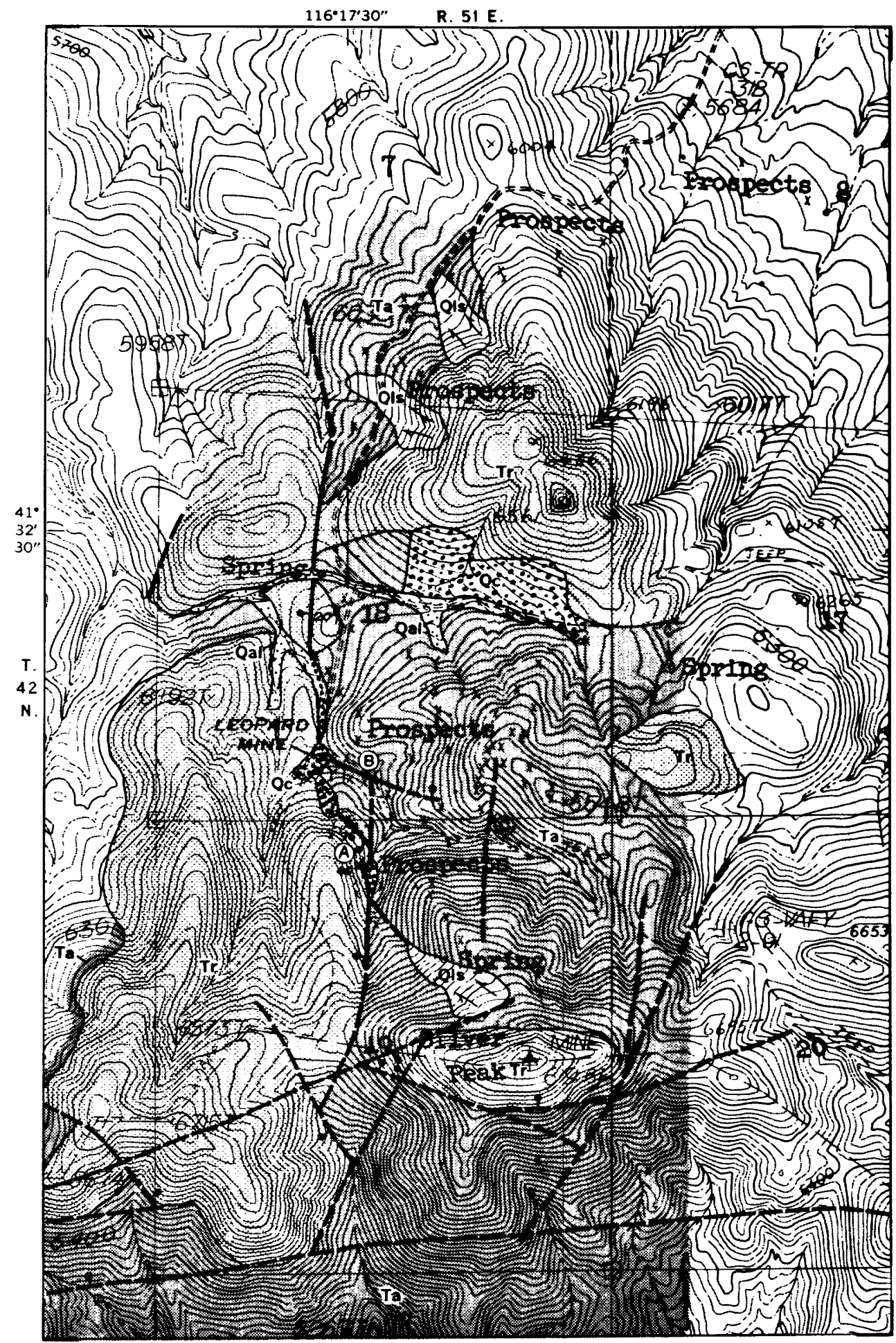

\section{EXPLANATION}

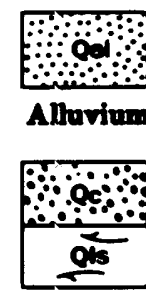

Colluvium and landalide deporits

Oc, cellnivial matorial and mine dumpo

O1s, landridide dopocits

unco seronmitr

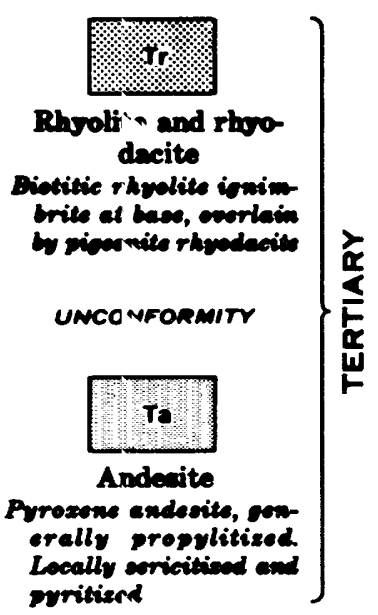

Contect

Position uncertain

(A)

Fault

Pendulam on down-

thrower side; deshal

where position is un

certaix. Lotter indi-

cates fault reforred to in text

120

Strike and dip of bod

Base enlarged from U.S. Geological Survey S.E. 1/4 Wilson Reservoir (1967)

0

$1 / 2$

1 MILE

Figure 2.-Geologic sketch map of the Cornucopia mining district. 
of rhyolitic and rhyodacitic rocks. The lower unit of these rocks, which in some places can be seen to rest on the andesite, is a biotitic rhyolite ignimbrite, the basal part of which is buff unwelded tuff that grades upward into a reddish-brown welded phase. Because of lack of exposures the maximum thickness in the area is not known. The minimum thickness is about 30 feet-measured in an exposure just west of the place where the road passes over the saddle which is near the center of sec. $18, T .42$ N., R. $51 \mathrm{E}$. The ignimbrite is overlain, possibly unconformably, by a dark, partly glassy, pigeonite rhyodacite containing much xenocrystic material. This rock forms the summit of Silver Peak and the surface of the long north-trending ridge immediately south of the mine shafts shown on the map.

The relations of the volcanics of Silver Peak to the mineralized andesite are critically important to the interpretation of the geology. Because of the prevalence of faulting and the ready disintegration of the tuffaceous lower portion of the ignimbrite, exposures showing the depositional contact are few. The most accessible exposure is in some artificial cuts about 0.4 mile cast and 0.45 mile north of the southwest corner of sec. 18. As the map reveals, faulting is prevalent in the Cornucopia area. Some of these faults display characteristics indicating that at least some of the movement on them is premineral; others may also be in part premineral, but either cut the mineral deposits, or displace the contact of the volcanics of Silver Peak and the mineralized andesite.

An example of a fault that is probably in part, at least, premineral is marked " $\mathrm{B}$ " in figure 2. At the time of my visit, it was reported by one of the persons engaged in exploration that the Leopard vein, which has been extensively worked under the mine dumps shown on the map, has been traced northward to the point where it is cut off by a silicified fault-vein trending northwest ( $B$ in fig. 2). A branch of this fault may be exposed in the portal of an adit on the south side of the gully that bounds the mined block on the north. The fault at the portal has a strike about $\mathrm{N}$. $10^{\circ} \mathrm{W}$. and dips about $70^{\circ}$ southwest. It also shows extensive silification. If, as the silicification along it suggests, this fault, or these faults, are premineral in age, the likelihood of finding a continuation of the Leopard ore body northeast of them is not great, although ore is known to occur in that area.

The volcanics of Silver Peak may be observed in fault contact with the mineralized andesite in a series of cuts about 0.4 mile east of the southwest corner of sec. 18. The buff, poorly consolidated, tuffaceous phase of the ignimbrite forms the hanging wall of a fault ( $\mathrm{A}$ in fig. 2 ) that trends northwest and dips from $36^{\circ}$ to $60^{\circ}$ southwest. The fault trace is marked by a brick-red gouge that contains fragments of quartz vein material up to 4 inches in diameter. In the gully to the east of this point, several cuts expose massive buff rhyolite tuff. Obscure bedding in the tuff dips west about $45^{\circ}$. This steep westerly dip is thought to be caused by drag on a normal fault that must pass just east of the cuts and follows the course of the north-trending gully.

The geologic evidence that suggests that the rhyolite and rhyodacite are postandesite is confirmed by the petrographic evidence. The buff tuffaceous lower part of the kiotite rhyolite ignimbrite has a substantial content of clear unaltered sanidine phenocrysts, green euhedral biotite tablets, phenocrysts of quartz and plagioclase, and equant fragments of vesicular black glass. It is not likely that tho biotite, sanidine, and glass would have survived unaltered while the adjacent andesite was boing intensely propylitized and sericitized.

The lack of mineralization ir the rhyolite and rhyodacite can thus be explained by the fact that they are younger thar the andesite and the mineralization. The faults that separate the rhyolite and rhyodacite from the mineralized andesite in the mine area are postmineral; the entire ridge that lies sonthwest of the area of active mining is part of a block, downthrown with respect to the blocks lying to the north and east. As the available exposures suggest that the most important ore-bearing veins of the district are cut off by these postmineral normal faults, extensions of these veins may exist beneath the rhyolite and rlyodacite. Unfortunately, the thicknesses of the rhyolite and rhyodacite units are not well krown both because an unknown amount of postdepositional erosion has occurred and because original 
thickness varied greatly from place to place due to deposition of the rhyolite and rhyodacite units upon an irregular surface. Hence, it is not possible to give a precise estimate of the throw of the fault on the northeast boundary (A in fig. 2) of the ridge block that lies south of the mine shafts. However, if the tuff of the rhyolite and rhyodacite unit, exposed west of the road in the west half of sec. 18, corresponds to the tuff exposed in the hanging wall of this fault, then the buried upper surface of the min- eralized andesite may be only a few scores of feet below the present ground surface, and concealed veins may offer attractive exploration targets.

\section{REFERENCES CITED}

Emmons, W. H., 1910, A reconnaissance of some mining camps in Elko, Lander, and Eureka Counties, Nevada: U.S. Geol. Survey Bull. 4C?, 130 p.

Granger, A. E., Bell, M. M., Simmons, G. C., and Lee, Florence, 1957, Geology and mineral resources of Elko County, Nevada: Nevada Bur. Mines Bull. $54,190 \mathrm{p}$. 